\title{
Think Tanks in the United States: The Evolution and Evolving Roles
}

\section{Jiangli Sua}

\begin{abstract}
Think tanks as an important force in the policy making field in the United States have strengthened their visibility and expanded their influence in recent decades. This paper contends that the historical and political climate of the United States has fostered the development of think tanks and they will continue to exert their influence in the policy making field of the United States. It mainly examines the history of American think tanks and the roles they have been performing during more than one hundred years' evolution. In the twenty-first century, in a more and more flattering world, policy issues become increasingly complicated, therefore think tanks are indeed fixtures of American policy making scene. They play six major roles: (1) source for policy idea; (2) venue for communicating and initiating new policy ideas; (3) source for personnel; (4) educating and informing the public; (5) evaluator of government policies; and (6) Track II diplomacy.
\end{abstract}

\section{Keywords}

Think tanks, policy making, public policy industry, policy idea, revolving door, Track II

Think tanks in the United States have endured tests and challenges of over hundred years' domestic and international upheavals. Their influence is on the rise and they have occupied high degree of visibility on the policy-making landscape. Using the connection between significant historical background and the landmarks in the evolution of think tanks as starting points, this paper seeks to examine the evolving roles of these major players in public policy research industry.

While exploring the evolving roles of think tanks in the United States, this paper concludes that transformation in American political environments as well as challenges and opportunities faced in the reality are the constant driving forces which fostered the flourish of these institutions devoted to creating and shaping public policy.

\section{THE HISTORY OF AMERICAN THINK TANKS}

Looking back on the history of public policy research industry, James McGann divided it into four stages: 1900-1929, 1930-1959, 1960-1975, and 1976-1990. And Donald E. Abelson classified it into four waves: (1) policy research institutions; (2) government contractors; (3) the rise of advocacy think tanks; and (4) vanity and legacy-based tanks (McGann 1992: 733; Abelson and Carberry 1998: 532-539).

This paper, however, believes that presenting the prevailing social climate which encouraged the

aShanxi University, China

Correspondent Author:

Jiangli Su, School of Foreign Languages, Shanxi University, No. 92 Wucheng Road, Taiyuan, Shanxi Province, China, postcode: 030006 
birth and development of these institutions will provide a revealing insight into the roles they performed.

\section{The Progressive Era and the Rise of Brookings Institution}

In the Progressive Era, faced with the prevalent social ills as child labor, the plight of the poor; the dominance of party bosses and party machines in the voting process and city management, and Robber Barons controlling almost every aspect of economic and political life, a group of philanthropists and conscientious industrialists placed high hope on social science and scientific management. They thought the professionalization of social science and scientific management would improve governance and enlighten public policy. As a result, the first groups of think tanks began to appear "as a part of large effort to bring the expertise of scholars and managers to bear on the economic and social problems of this period" (Smith 1991: 120). The Russell Sage Foundation, Brooking Institutions, and National Bureau of Economic Research, each of these institutions owed its origins to different business and professional groups that were the major players in social reform movement of this period.

For example, out of the ideal to bring efficiency and scientific expertise to public policy-making, Robert S. Brookings, a St. Louis industrialist and philanthropist created three institutes: Institute for Government Research, Institute of Economics, and the Robert Brookings Graduate School of Economics and Government. The three were merged to form Brookings Institution in 1927 with the mission to promote, conduct, and foster research in the broad fields of economics, government administration, and the political and social sciences. It was the first private organization devoted to analyzing policy issues at the national level based on the principle of applying scientific methods to the management of government. When pursuing "scientific investigation into the theory and practice of governmental administrations", it played an important role in the reform thinking that led to the passage of Budget and Accounting Act of 1921 and the creation of first U.S. Bureau of the Budget (Smith 1991: 256).

In order to combat the Great Depression, President Franklin Roosevelt formed Brain Trust to provide his New Deal programs with strategies, directions, and attainable goals. And these new programs and new agencies generated large demand for scholarly and academic analysis. Brookings Institution became an independent voice to examine and evaluate the New Deal programs and its experts criticized the New Deal policies as being drifted into "unchartered sea”, if not “state socialism” (Dixon 1972: 19). According to Weaver (1989: 565), "Brookings acquired a reputation first as a conservative foe of the New Deal, later as a liberal proponent of the Great Society, and most recently as an institution that strives for the center". In this sense, Brookings established itself for seeking to maintain adequate independence to preserve the integrity of its policy research.

In the World War II era, Brookings experts helped the government to refine the blueprint for President Franklin D. Roosevelt's dream of the United Nations and shaped the structure and operating procedures of the Marshall Plan.

According to McGann (1992: 734), "Its attempt to bring knowledge and expertise to bear on public policy has influenced the nature and design of public policy institutes for over 50 years”. Thus, Brooking Institution as the first independent organization dedicated to conducting public policy research sets the example for think tanks to provide scholarly, objective analysis of public policy and teach the public on policy-making issues. And it declares that its "mission is to conduct high-quality, independent research and, based on that research, to provide innovative, practical recommendations that advance three broad goals: strengthen American democracy; foster the economic 
and social welfare; security and opportunity of all Americans; and secure a more open, safe, prosperous and cooperative international system" (About Brookings, Brookings Institution 2012).

In recent years, Brookings has been continuously ranked as number one think tank worldwide and the best think tank in the United States by "Global Go To Think Tanks" project conducted by University of Pennsylvania.

\section{WWI and the Flourish of Foreign Policy Research}

After the outbreak of the First World War, by the desire to "hasten the abolition of International war, the foulest blot upon our civilization” (Carnegie at 100: A Century of Impact 2012), Andrew Carnegie donated \$10 million to create the Carnegie Endowment for International Peace in 1910. In fact, a series of domestic and foreign policy challenges brought about by WWI led to the creation of a number of public policy research institutes like Carnegie Endowment, Foreign Policy Association (1918), Hoover Institution on War, Revolution and Peace (1919), and Council on Foreign Relations (CFR) (1921), which were formed in response to United States' emergence as a global power.

Concerning the roles performed by these institutes, George Fauriol, vice president of National Endowment for Democracy and senior associate of CSIS (Center for Strategic and International Studies) Americas Program pointed out, these institutes "were clearly the outgrowth of America's domestic economic and overseas diplomatic expansions" (Fauriol 1984: 11). Because of the isolationist legacy of George Washington, American political elites and public were concerned about the deep involvement in international politics. Those institutes wanted to inform, convince, and educate American people and the policy makers that it was in the interest of the United States to play a greater role in international politics by conducting foreign policy research and education.

\section{World War II, Cold War and RAND Corporation}

Like the Progressive Era which led to the birth of Brookings Institution, the Second World War and the Cold War at the wake of it marked a new stage in the evolution of think tanks in the United States. It is during this period, institutes like RAND (acronym for research and development) Corporation, Foreign Policy Research Institute, The Center for Strategic and International Studies, and The Hudson Institute emerged. While the focus and structure is different, the political climate that shaped them is similar. Growing out of the surroundings that molded the four above mentioned institutes, American Enterprise Institute for Public Policy Research was an exception. It decided to exert its influence when economy was transforming from war time model to peace time economy.

In any case, RAND Corporation turned out to be a major departure from the Brookings model. Established in 1948, RAND assumed the role of contractor researcher for the Department of Defense (DOD). By tapping into the expertise of engineers, physicists, biologists, statisticians, and social scientists, RAND devoted to advising the Air Force on how to defend U.S. against enemy attacks. It also made great contribution to strengthening the United States' nuclear deterrent. But what made it excellent was that RAND researchers played an important role in major innovations in management and analytical techniques of the 1950s and 1960s, especially PPBS (Planning-Programming-Budgeting System) and systems analysis. Adopting the techniques perfected by the research and development industry to promote the analysis of public policy, RAND scientists were bold enough to "think about the unthinkable". And Patricia Linden said that "RAND with its thorough, objective methods of analysis and multi-disciplinary approach have been copied by problem solvers in every field and are paradigms for the Urban and Hudson 
Institutes” (Liden 1987: 106). Thus, largely due to its groundbreaking innovation in research methods, RAND served as a prototype for other institutes. From the 1946 report about the first satellite design, the pioneered studies about former Soviet Union, the first program-based budget for the Air Force, NATO (North Atlantic Treaty Organization) force planning to the effects of vouchers and charter schools on academic achievement and health problem, RAND research spans the issues that matter most, such as energy, education, health, justice, the environment, and international and military affairs. Today, RAND is still a quintessential U.S. federal government contractor, $79 \%$ of whose total revenue comes from DOD, U.S.

Air Force, U.S. Department of Health and Human Services, and U.S. Army. Its revenue for FY (Fiscal Year) 2015 is 293.3 million of which 231.4 million derives from contract research (RAND at a Glance 2016).

\section{Great Society and the Urban Institute}

Think tanks in the United States were striving to expand their intellectual reserves to offer insights into domestic public policy research, especially urban problems when President Lyndon Johnson launched War on Poverty and persuaded "the Congress to pass a vast array of social welfare legislation, known collectively as the Great Society Programs” (Bailey and Kennedy 1991: 441). During this period of time, domestic social policy think tanks thrived because the implementation of these new programs produced great demands for non-partisan, objective, scientific analysis and advice. Domestic policy-oriented Urban Institute assumed a prominent role in the policy-making process. At the start-up stage, ninety percent of its funding came from government departments, especially Housing and Urban Development. Since its founding, Urban Institute's researches have centered on domestic issues such as housing, health care, education, tax, welfare and families as well as the implications of demographic changes.
During that period of time, almost all major think tanks began to develop domestic, social, especially urban programs.

\section{The Influence of Neoconservatives and the Nouveau Riche, Heritage Foundation}

If Great Society programs encouraged think tanks to engage in domestic policy research on contract basis, the Regan "revolution" which raised the influence of neoconservatives, virtually, sparked the prosperity of a new brand of think tanks. The new think tank models are often collectively labeled as advocacy think tanks.

Unlike traditional research institutions, advocacy think tanks are not driven by the desire to advance objective, scholarly research. On the contrary, they "combine a strong policy, partisan or ideological bent with aggressive salesmanship and an effort to influence current policy debate” (Weaver 1989: 567). This new breed of think tanks challenged the Brookings and RAND models about how think tanks should be organized and operated. Patricia Linden (1987: 100) observed that: "A new breed of think tank sprang up; politically purposeful bodies whose mission is to back the new conservative movement or fight it. At the same time, the established tanks broadened the scope of their studies and joined the swelling debate over government's national and foreign policies".

That's why Andrew Rich (2004: 206) remarked that "formerly neutral arbiters, think tanks are increasingly becoming ideological advocates". Heritage Foundation best exemplifies this new brand of think tanks. Ronald Regan's election in 1980 provided a turning point for Heritage Foundation and the development of think tanks in the United States. Edwin Feulner, founder and president of Heritage Foundation declared: "What made the Heritage name was when Ronald Regan called us both his favorite think tank and the feisty new kid on the conservative block” (Katz 2011: 5). From his perspective, they have made an effort to "become part of the political 
process" (Abelson and Carberry 1998: 538). That means they are trying to remove the detached distance between policy-making researchers and policy-makers.

\section{THE EVOLVING ROLES OF AMERICAN THINK TANKS}

Tracing the evolution of these major players in public policy making arena, a close link between political environment and the role of think tanks can be found. From Brookings and RAND models to advocacy think tanks like Heritage Foundation, think tanks assumed new tasks to adjust to the changing political climate. To compete for influence and fund and to enhance their visibility in the marketplace of idea, Brookings and RAND have adopted some of the strategies employed by newer ones and expanded their roles in public policy research industry. On the other hand, newly created institutions have looked to them for examples on how to enlarge their influence. In short, "they co-existed in the policy making community" (Abelson and Carberry 1998: 532).

Therefore, despite their different organizational structure and perspectives, think tanks in the United States perform a number of basic roles: (1) source for policy idea; (2) venue for communicating and initiating new policy ideas; (3) source for personnel; (4) educating and informing the public; (5) evaluator of government policies; and (6) Track II diplomacy.

\section{Source of Policy Ideas}

The basic function of think tanks is to generate ideas that have the potential to promote reform or change in a specific area. For instance, Kent Weaver (1989: 568) thought, "One of the tasks commonly associated with think tanks is the exploration and popularization of ideas that may not be politically feasible in short term, but gradually gain acceptance among policy makers and eventually find enough champions that can be enacted". In terms of foreign policy making, Richard Haass (2002: 6) said, "Their greatest impact is in generating 'new thinking' that changes the way that U.S. decision makers perceive and respond to the world”. Through generating new ideas, they are able to provide new insights into the emerging challenges and opportunities the nation is facing and impact policy makers' perceptions of national interests as well as the agenda of policy issue accordingly.

Therefore, think tanks are committed to shaping policy preferences and the choice of policy makers which also propels them to devote considerable resources to developing and promoting ideas to grab the attentions of policy makers. They rely on different channels: (1) publishing books, reports, occasional papers, and conference proceedings; (2) writing articles for influential newspapers, magazines; (3) having interviews with TV and radio programs; (4) producing timely issue briefs, fact sheets, and backgrounders; (5) creating web pages allowing visitors to download institute publications, give comments on expert's opinions, and track the blogs of the institute's experts; also (6) promoting their images and influence on social media like Twitter and Facebook. Besides, congressional hearings are also a viable means to influence policy preference. For example, Brookings Institution publishes about "50 new titles" each year on important policy issues ranging from economics, government to national security and international relations (McGann 2007: 37). They also publish several journals including Brookings Review, RAND Review, Washington Quarterly from CSIS, and International Security published by Belfer Center for Science and International Affairs to attract a large amount of readers for their fresh and deep insights. Without doubt, Foreign Affairs adds extra weight to CFR. E-Journals also become an important channel amid the flourish of the Internet technology. CSIS operates several e-journals: Comparative Connections, PacNet, Southeast Asia From the Corner of 18th \& K Streets, etc.

Testifying before congressional committee can bring think tanks with opportunities to plant ideas in 
the minds of members of Congress concerned with the issues and provide them with ammunitions in policy debate, a fresh perspective, or some additional reinforcement for their positions.

As source of policy ideas, particular historical juncture and sudden outbreak of crisis are always the acid test for the credibility of think tanks. CFR has established itself firmly among the top think tanks of the United States largely because of its massive War and Peace Studies Project, which to a certain degree has left its mark on the post-WWII arrangements. The Project had finally provided the U.S. Department of State with "682 memoranda" ranging from "the occupation of Germany to the creation of the United States" (Abelson 2006: 6). Certainly, the publication of the George Kennan's article "The Sources of Soviet Conduct" anonymously named $\mathrm{X}$ in the byline in Foreign Affairs in 1947 has become the classic example of the influence of think tanks. With the publication of Samuel Huntington's "The Clash of Civilizations" in 1993, Foreign Affairs renewed its scorecard.

Since September 11, 2001, Brookings Institution, CSIS, Heritage Foundation, and Project for the New American Century have contributed to the discussions and policy shaping of the government. For example, Brookings has launched a series of projects on anti-terrorism, homeland security, and U.S. policies to the Islam world. It has also submitted several reports about national security and the assessment of Bush administration's anti-terrorist strategies to U.S. government. Confronted with "the Great Recession" of 2008-2009, Brookings scholars probed its causes and consequences, shaping debate with a steady stream of analysis and recommendations.

Presidential campaign provides think tanks with opportunities to help shape the foreign policy stance and agenda of the candidates. Besides, think tank experts are also provided with the chances to serve on policy task force and transitional teams to assistant presidential candidates and president elected to define foreign policy strategies. The Heritage Foundation providing President Regan with blueprint is the most cited example. Heritage's 1,093-page public policy blueprint-“Mandate for Leadership: Policy Management in a Conservative Administration”, once became the blueprint of the newly elected Reagan administration on everything from taxes and regulation to crime and national defense. The new president gives copies to every member of his Cabinet at their first meeting. According to Heritage Foundation's 35th anniversary achievement display, "Nearly two-thirds of the 2,000 recommendations contained in Mandate were adopted by the Reagan administration” (Heritage Foundation's 35th Anniversary 2012).

In 1992, IIE (Peterson Institute for International Economics) and Carnegie Endowment suggested the incoming Clinton administration to form an "Economic Security Council". The proposal was adopted by the Clinton administration. Now the Economic Security Council becomes an advisory body of the Executive Office of the President as important as the National Security Advisor.

\section{Source of Personnel}

In the U.S., the new president has the authority to appoint hundreds of mid-level and senior executive positions in his camp of bureaucracy. Think tanks serve as a steady source of personnel to fill the vacancy. Haass (2002: 6) claimed: "This function is critical in the American political system”. Actually, it is also critical to think tanks' influence in policy making, in a way their counterparts in parliamentary system cannot even think about. Abelson (2006: 153) viewed them as "talent pool" or "holding tanks" where policy experts congregate in hope of being recruited into senior government positions.

Besides providing expertise to administration's executive branch, think tanks may also provide a "government in exile where official of the party whose presidential candidates has been defeated can seek 
gainful employment while they lick their wounds, wait for their party to come back to power and come up with new ideas" (Weaver 1989: 569). Pertinent to foreign policy making, Haass (2002: 7) saw this as "informal shadow foreign affairs establishment". Research positions offer the departing officials the environment to share their insights gained from government service and contribute to policy debate from a more detached position. In this political ecology, think tanks thrive by assembling talents for the government on the one hand, and fostering close ties with policy makers on the other.

So, the revolving door has been an ad hoc one. It is a task long associated with think tanks. Haass (2002: 8) regarded it as "unique to the United States", and a "source of strength".

\section{Venue for Communicating and Initiating Policy Ideas}

Given their non-partisan and academic settings, think tanks are ideal venue to build shared understanding in the foreign policy community, or among the "foreign policy public" labeled by Ernest May. Think tanks regularly host events, seminars, workshops, luncheons, and dinner parties. These events convene government officials, pundits, and the media to discuss policy issues. For instance, Brookings Institution claims by holding events, it offers a platform to policy experts and world leaders to bring expertise and informed debate to public discussion of policy choice. CFR hosted 159 events in 2011. Brookings held about 400 events in 2012, and Carnegie Endowment held 101. CSIS hosts more than 1,600 events each year, from major public conferences to small private briefings. CSIS also hosts several formal events series, including the CSIS-Schieffer Series Dialogues, the Russia Balance Sheet Speaker Series, the Statesman's Forum, and the Trans-Pacific Partnership Speaker Series. Center for a New American Security has hosted more than 300 events concerning security issues since it was created in 2008.

For policy makers, participating in events at think tanks offers them with an academic atmosphere to announce new initiatives, explain current policy, and launch trial balloons for future plans. For example, before beginning her first trip to Asia, also her first trip as Secretary of State, former Secretary Clinton delivered a speech at Asia Society to express the administration's desire to engage Asia more closely. Later in August 2010, she gave the speech “America's Engagement in Asia” at East West Center in Hawaii. The speech presents important framework for the administration's rebalancing toward Asia-Pacific region. On November 10, 2011, she gave her “America's Pacific Century” remarks at East-West Center (EWC) in Hawaii. The remarks marked the Obama administration's rebalancing to Asia-Pacific.

On the other hand, for think tanks, these events provide them with chances to get access to members of Congress and bureaucracy. To boost their influence, gaining access to members of Congress and their staff, as well as important committee and subcommittees, is one of the important tasks of think tanks. Many maintain liaison offices with the bicameral legislative body. Besides, being summoned to White House to discuss policy issues with president and his inner circle of advisers is a proof of a tank's experts' credibility. If becoming members of presidents' advisory boards or task force, they are in a position to exercise extraordinary influence. So they often invite presidential advisors to host events to build the channels to White House.

In addition, think tanks cannot afford to ignore bureaucracy, especially those in the Departments of Defense, State and Homeland Security, because they are important members of the foreign policy community. So, they also create and maintain communication channels like RAND's Policymaker Education and Training Programs.

CNAS (Center for a New American Security) launched the Next Generation National Security Leaders Program in 2009 as part of its mission to cultivate the next generation of national security 
leaders and encourage a shared understanding of the nation's security interests and international priorities. In the Next Generation National Security Leaders Class of 2012-2013, there are 16 emerging leaders having diverse backgrounds and experience across the national security field, including in the executive and legislative branches, the U.S. military, academia and the private sector. The 2016 Class includes staffs from United States Army, Navy, Air Force, Marine Corps, Executive Office of the President, DOD, Policy Planning Staff from Department of State and Deputy National Intelligence Officer.

\section{Educator}

Think tanks also serve as educational institutions to engage and inform the public about the changing world they are living in, American national interests, and the emerging challenges and opportunities the nation is facing. The Global Interdependence Initiative based at Aspen Institute was launched in early 1999 and is conceived as a ten-year effort to better inform, and more effectively motivate, American public support for forms of U.S. international engagement that are appropriate to an interdependent world. Actually, Aspen is also a policy education institute. The Institute has campuses in Aspen, Colorado, and on the Wye River on Maryland's Eastern Shore. It also maintains offices in New York City and has an international network of partners.

Established by the United States Congress in 1960, the EWC is designed to be an educational institution to foster better relations and understanding among the peoples of the United States, Asia, and the Pacific islands through programs of cooperative study, training, and research. The Center serves as a resource for information and analysis on critical issues of Asia Pacific, bringing people together to exchange views, build expertise, and develop informed policy options.

Besides informing social elites and common public, nurturing young people's global vision is also a pursuit of think tanks. The Young Leaders Program at Pacific Forum CSIS selects up-and-coming young professionals and post-graduate students to participate in a series of Pacific Forum policy dialogues and conferences, which are normally open to seasoned experts. The program serves as a catalyst for training young professionals in international policy affairs at an early juncture in their careers, while also giving greater voice to the younger generation's viewpoints within the elite circles of policy specialists.

Meanwhile, the websites and publications of the think tanks are also useful channels to educate the public about U.S. foreign policy. Especially, they publish some widely circulated journals like Foreign Affairs, Washington Quarterly, Foreign Policy, and $R A N D$ Review which are well received among the public.

\section{Evaluators of Government Programs}

Once a policy is enacted, its implementation and effects will be monitored by the congressional committees. Think tanks are often used as independent evaluators to assess whether a policy is operating effectively and achieving the expected objectives. Most of these assessments are undertaken on contract basis. For example, when DOD has released the new strategic defense guidance and decided to rebalance toward Asia Pacific, the House Armed Service Committee requires the DOD to commission an independent organization to assess the force posture of the Pacific Command Area of Responsibility. CSIS has been chosen by the DOD. On August 1, 2012, co-directors of the CSIS assessment project testified before the committee to account for the findings of their assessment.

\section{Track II Diplomacy}

Think tanks can capitalize on its expertise and independence to directly play a part in foreign policy arena by hosting events, sponsoring sensitive dialogues, or meditating as a neutral force for parties in conflicts. 
Take Carnegie Endowment as example, in late 1980s, the Carnegie Endowment held its first International Non-proliferation Conference which provided opportunities for policy and technique experts and government officials to grapple with urgent threats and advance the debate that continued to shape the non-proliferation regime. It has since grown into the premier event in the non-proliferation world. 2013 Carnegie International Nuclear Policy Conference brought together over 800 experts and officials from more than 45 countries and international organizations to discuss emerging trends in nuclear non-proliferation, strategic stability, deterrence, disarmament, and nuclear energy (100 Years of Impact: A Timeline of Carnegie Endowment for International Peace 2016). In the mid-1980s, the Carnegie Endowment hosted a series of meetings in Washington, to bring together South African political elites and U.S. government officials as well as members of Congress. These gatherings, lasting for over eight years, have facilitated the political transition of South Africa by helping to build shared views on the future of the country (Haass 2002: 8).

As a non-partisan and federally funded institution, the U.S. Institute for Peace (USIP) has been created by the Congress to conduct Track II diplomacy because USIP experts can engage in unofficial dialogue with diplomatic entities in a way that the official U.S. government cannot. The institution is training its employees to become experts on how to resolve conflicts, end or prevent violence. It seeks to prevent, manage, and resolve violent international conflict by promoting post-conflict stability and development. USIP experts work in more than 30 countries including Sudan, South Sudan, Afghanistan, Pakistan, and Iraq.

Established by the United States Congress in 1960, the EWC is the country's national educational institution to foster better relations and understanding among the peoples of the United States, Asia, and the Pacific islands through programs of cooperative study, training, and research. Over more than 50 years of serving as a U.S.-based institution for public diplomacy in the Asia Pacific region with international governance, staffing, students, and participants, the Center has built a worldwide network of 62,000 alumni and more than 950 partner organizations. The impact of the EWC is far-reaching. Its network of alumni and partner groups includes many who currently hold positions of leadership throughout the United States and the Asia Pacific. Having alumni as heads of government, cabinet members, university and NGO presidents, corporate and media leaders, educators, and prominent individuals is a great asset for conducting Track II diplomacy.

\section{CONCLUSIONS}

Victor Hugo once observed: "Greater than the tread of mighty armies is an idea whose time has come”. These idea brokers stepped onto the stage of public policy industry at the dawn of the twentieth century and enhanced their influence when experiencing challenges and tests of critical historic moments. By examining their evolution and roles played in American policy making arena amid the opportunities and trials of the country's coming out at the beginning of the twentieth century to the twenty-first century, this paper draws its conclusion that think tanks in the United States will continue to thrive and exert a more important influence in the future.

\section{References}

100 Years of Impact: A Timeline of Carnegie Endowment for International Peace. 2016. Retrieved (http://www.carnegie endowment.org/about/timeline100/index.html).

Abelson, D. E. 2006. A Capitol Idea: Think Tanks and US Foreign Policy. London: McGill-Queen's University Press.

Abelson, D. E. and C. M. Carberry. 1998. "Following Suit or Falling Behind? A Comparative Analysis of Think Tanks in Canada and the United States." Canadian Journal of Political Science 31(3):525-555. 
About Brookings, Brookings Institution. 2012. Retrieved (http://www.brookings.edu/about/ research-Programs/).

Bailey, T. A. and D. M. Kennedy. 1991. The American Spirit. 7th ed. Lexington: D.C. Heath and Company.

Carnegie at 100: A Century of Impact. 2012. Retrieved (http://carnegieendowment.org/about/?fa= centennial).

Dickson, P. 1972. Think Tanks. New York: Atheneum.

Fauriol, G. 1984. "Think Tanks and U.S. Foreign Policy." Presented at the Fourth Tamkang American Studies Conference, Center for Strategic and International Studies.

Haass, R. L. 2002. "Think Tanks and U.S. Foreign Policy: A Policy Maker's Perspective.” U.S. Foreign Policy Agenda 7(3):5-8. Retrieved (http://www.scribd.com/doc/3210628/ the-role-of-think-tank-in-us-foreign-policy.pdf).

Heritage Foundation's 35th Anniversary. 2012. Retrieved (http://www.heritage.org/about/or-history/35thanniversary).

Katz, L. M. 2011. “American Think Tanks: Their Influence Is on the Rise.” Retrieved (http://www.carnegie.org/reporter/ 18think_tank/index9.html).

Linden, P. 1987. "Powerhouses of Policy: A Guide to America's Think-Tanks.” Town and Country.

McGann, J. G. 2016. “The Global 'Go-To Think Tanks'.” Think Tanks and Civil Society Program 2016. International
Relations Program, University of Pennsylvania, Philadelphia, PA, USA, 19104-6305.

1992. "Academics to Ideologues: A Brief History of the Public Policy Research Industry.” PS: Political Science and Politics 25(4):733-740.

. 2007. Think Tanks and Policy Advice in the United States. NY: Routledge.

RAND at a Glance. 2016. Retrieved (http://www.rand.org/ about/glance.html).

Rich, A. 2004. Think Tanks, Public Policy, and the Politics of Expertise. Cambridge: Cambridge University Press.

Smith, J. A. 1991. The Idea Brokers: Think Tanks and the Rise of New Policy Elite. New York: Free Press.

Weaver, K. R. 1989. “The Changing World of Think Tanks.” PS: Political Science and Politics 22(3):563-578.

\section{Bio}

Jiangli Su, MA in English language and literature, lecturer, School of Foreign Languages, Shanxi University, China; research fields: American literature, American history, and politics. 